\title{
STUDENTS SPEAKING ACTIVITIES AT VIJAYA LEARNING CENTRE
}

\author{
Syafaruddin Marpaung, S.Pd, M.Hum \\ English Instructor at Vijaya Learning Centre \\ syafarudinmrp@yahoo.co.id
}

\begin{abstract}
The objective of this research is to describe the students speaking activities atVijaya Learning Centre (VLC). The subject of this descriptive research is the students in 2017-2018 academic year. The researcher uses descriptive qualitative research. There are two types of data; primary and secondary. The primary data are taken from the first resources through the direct observation, while the secondary data are taken from the second resources that can be such us document. The writer collects the data of this research from the process of speaking skill, interview with the students, teachers, document, and observation. To analyze the data, the researcher employs descriptive qualitative analysis. The analysis started by data reduction then data display and the last step is conclusion drawing. The results of this research show that: (1) the students' speaking activities covered role play, story telling, acting from script, interview or questions and answers, retelling with pictures, brainstorming (prepared short talk), and drilling or memorizing. (2) the problems faced by the students in speaking skill are limited number of words, pronunciations, and lack of self confidence. (3) The teachers use mobile phone to record and upload the result of speaking videos. Parents and viewers can give comments, opinions and praises from the uploaded videos in social media. In solving problem related to the vocabulary and pronunciation problem, the teachers give correction directly and use repetition in recording.
\end{abstract}

Key words : Speaking Activities; VLC

\section{INTRODUCTION}

In teaching and learning English, there are four basic language skills that should be mastered namely: listening, speaking, reading and writing. Speaking skill is one of the crucial parts of second language learning and teaching. As one of the language skills, it enables people to communicate directly each other and also plays an important role for the success of language learning. According to Richards and Renandya in Widiati and Cahyono (2006:1), a large percentage of world's language learners study English is in order to develop proficiency in speaking. Students of second/foreign language education programs are considered successful if they can communicate effectively in the language (Riggenback and lazaraton, 1991 in Widiati and Cahyono, 2006; 1).

The purpose of speaking skill is for communication. Communication canfunction not only as a tool of interaction with other people but also media to solveall problems faced by them. Speaking naturally is designed to do just that: teachstudents how to perform certain language functions in English by presenting thesocial rules for language use (Tillitt :1985). Mastery the speaking skill will carry out a conversation. establish and maintain social relations, and interactional function, which focus on the exchange of information. But making students speak in the class is not easy because most students assume English is very difficult. The difficulties of students to speak are caused by some reasons such as students' reluctance, lack of motivation, and uninteresting teaching technique. In addition, in speaking skill students should also master several elements which are important such as: pronunciation, grammar, vocabulary, fluency, and comprehension.

Vijaya Learning Centre (VLC) is one of the English tutorials Tanjungbalai. This institution was established in 1971 and at that time the name of this course was Gandhi English Course. The founder of this course wasThirunyanam B.A and in 1990 this course changed its name into Vijaya Language Learning Centre (VLC) and still exists till nowadays and gets good appreciation from Tanjungbalai society. This institution offers English and Computer training. There are many levels prepared in English course namely ; Kindergarten I-IV, Primary I - VI, Standard I-IV, Course I - VI, Level I-VI, and Special Class Conversation and TOEFL and IELTS preparatory class. Each stage lasts 
four months except in Level classes, where students get examination every six months. VLC always follows English development and keep changing and improving the quality of teaching based on the societies' needs. Every class in VLC only consist of 10 till 15 students so the teachers and students closely can interact each other. In small classes, the English teaching learning process can effectivelybe conducted and the goal of learning English can be achieved accurately.

In learning speaking skill, some of Vijaya Learning Centre(VLC) students also often find some problems. The problem frequently found is that their native language causes them difficulty in using the foreign language. Other reason is because of lack of motivation to practice the second language in daily conversation. They are also further shy and afraid to take part in an English conversation. They are not brave enough to go ahead and speak in front of the class. Luckily, some students always perform their ability in speaking. They directly stand in front of the class, speak in English and convey ideas, opinions or practice among their friends without hesitation. It is estimated that there is $50 \%$ of the students amount in the class that still are doubtful, afraid to perform speaking skill. Realizing this problem, the teachers in VLC are never bored and hopeless to motivate all the students to present speaking skill in front of the class. They warmly apply the speaking techniques in teaching learning activity. They are open to receive and modify the change in teaching learning process based on the English teaching development.

There are some activities conducted by the students in performing their speaking skillnamely ; role play, Interview or Questions and Answers, storytelling, retelling with pictures, drilling and brainstorming activity. Each activity is practiced by the students based their level and the material prepared. The teachers also use technology in conducting teaching learning process. Mobile phone is used to record and upload the result of speaking skill. Parents and viewers also can give comments, praises and motivation for the result of record through social media such as facebook, instagram and youtube.

From the explanation above, the researcher will observe the activities practiced by the VLCstudents andteachers in presenting speaking skill, how the students conduct theseactivities, and what problems are faced by the students and teachers in achieving speaking skill.

\section{RESEARCH METHODOLOGY}

This study used a descriptive qualitative method to obtain the data and to answer the research questions. This method was used because this study was addressed to certain situation that actually happened to the subject of the study, which was students speaking activities at Vijay Learning Cetre (VLC).There are two main participants it this research, namely ; students and teachers. Vijaya Learning Centre's students from the lowest level (K1) to the highest level an eleventh grade of (SCC), and all teachers were given the research questions through questionnaire and interview to answer and obtain the data. To get deeper data, the classroom observations were done. Since the data of this study would be described by using words rather than numbers, the descriptive qualitative method was the most appropriate one for this study.

\section{THE PURPOSES OF THE STUDY}

The purpose of the study in this research aredescribe the students speaking activities at Vijaya Learning Centre (VLC).

\section{THE OBJECTIVE OF THE STUDY}

The objective of the study is how to look the speaking activities of students at Vijaya Learning Centre (VLC).

\section{FINDINGS AND DISCUSSIONS}

\section{Speaking Skill}

Speaking is the process to deliver ideas, opinions, or something in someone's mind in oralform. When attempting to speak, learners must muster their thoughts and encode those ideas in thevocabulary and 
syntactic structures of the target language. Chaney (1998) states speaking is "the process of building and sharing meaning through the use of verbal and non-verbal symbols, in a variety of contexts". It is considered by learners as one of the most difficult skills as it involves real-time processing which means thatlearnershaveless time to formulate what they want to say and how to say it. For many years, teaching speaking component has been undervalued and English language teachers have continued to teach it just as a repetition of drills or memorization of dialogues.

Brown (2001: 267) cites that when someone can speak a language it means that he can carry on a conversation reasonably competently. In addition, he states that the benchmark of successful acquisition of language is almost always the demonstration of an ability to accomplish pragmatic goals through an interactive discourse with other language speakers. However, today's world believes that the goal of teaching speaking component should improve students' communicative skills, because, only in that way, students can express themselves and learn how to follow the appropriate social and cultural rules in each communicative circumstance. Speaking is a productive skill and one of the important parts of second language learning. The ability to communicate in a second language clearly and efficiently contributes to the success of the students in school and later in every phase of their life.

Based on the explanation above it can be concluded that speaking skill is always related to communication. Speaking skill itself can be stated as the skill to use the language accurately to express meanings in order to transfer or to get knowledge and information from other people in the whole life situation.

\section{Principles of teaching speaking}

Brown (2001) classifies that there are principles for designing speaking techniques such as using techniques that cover the spectrum of learner needs, from language-based focus on accuracy to message-based focus on interaction, meaning, and fluency. Furthermore, providing intrinsically motivating techniques and encouraging the use of authentic language in meaningful contexts are also the principles of teaching speaking. Finally, providing appropriate feedback and correction, capitalizing on the natural link between speaking and listening, giving students opportunities to initiate oral communication and encourage the development of speaking strategies are also considered as principles of teaching speaking. Thus, all of the principles of teaching speaking contribute to the type of activities used in the classroom such as simulation and role-play.

\section{The components of speaking skills}

There are three components of speaking required to enhance the speaking skills. Those components are accuracy, fluency and comprehensibility. If a student speaks accurately, he or she is capable of constructing sentences and longer stretches of language that follows acceptable rules of usage. Parrot (2002) described accuracy as the ability of learners in using appropriate grammar, vocabularies and phonology in their speaking. In general, accuracy is related to the way of students in mastering word order and omission, pronouns and relative clauses, tenses, prepositions, and producing correct sentences in pronunciation, and other grammar rules that commonly occur when they are speaking among them, so their speaking can be understood by others.

One of the goals of teaching speaking is to develop fluency in language use. Fluency is natural language use occurring when a speaker engages in meaningful interaction and maintains comprehensible and on going communication despite limitations in his or her communicative competence. Richards, Platt, and Weber (1985) states that fluency is the features which give speech the qualities of being natural and normal, including native-like use of pausing, rhythm, intonation, stress, rate of speaking, and use of interjections and interruptions. Fluency can be developed by creating classroom activities in which students must negotiate meaning, use communication strategies, correct misunderstandings and work to avoid communication breakdowns.

Comprehensibility is the process of understanding of the utterances sent by the speaker done by the listener. Comprehensibility in speaking means that the people can understand what we say and we can understand what they say. Harmer (2005)states that if two people want to have communication, they have to be speaking because of different information they have. Bad communication occurs when people still confuse with the information received. Therefore, simulation and role-play activities can strengthen these three components to increase speaking skills because it provides a lot of communication practices to the students. 


\section{Students Speaking Activities at VLC}

Teaching speaking should be taught in attractive and communicativeactivities. There are many types of classroom speaking activities. Harmer (2001) states six classroom speaking activities. They are acting from script,communication games, discussion, prepared talks, questionnaires, simulation, androle play.They are conducted in pairs or with others students. Other activities categorized in speaking activities are story telling, picture story, short speeches, etc. These activities are done alone and calling it as monologue. In Vijaya Learning Centre (VLC) students also apply almost all these activities. These activities widely will be described as below :

\section{Role Play}

Role play is a method of acting out particular ways of behaving or pretending to be other people who deal with new situations. In this case, Ladousse (1995) argues that when students assume a "Role", they play a part (either their own or somebody else) in specific situation. "Play" means that is taken on in a safe environment in which students are joyful and playful as possible.According to Brown (2004) "role play is a popular pedagogical activity in communicative language-teaching classes". It makes the students free to be someone based on their creativity linguistic input. In line with Brown, Nunan (2003) also states that role play activities are important in the teaching of speaking because they give the students an opportunity to practice communicating in the different social contexts and target language.

In VLC speaking teaching learning process, students apply these activities in every level, from the lowest to the highest class, based on the material given. In the low level, Kindergarten, Primary, and standard class, the students only memorize and act the role from the text book or dialogue sources. While in the higher levels, like level grade and SCC, students can improvise, and expand the expressions from the dialogue scripts because the students mostly have had many vocabularies and able to build sentences without long preparations. They can act out the role of completely different characters and express thoughts and feelings as they doing in the real world.

The smart students only have to read the script or situation theme given by the teachers. They will discuss the topic and situation in a group, and if they have problem or do not know some vocabularies, they will open the mobile dictionary or ask the teachers. In VLC the wi-fi facility is available for the students in course time. After preparing a moment, they directly practice the dialogue in front of the class. The teachers just supervise and motivate the students to practice speaking skill in front of the class. Teachers also record this act through mobile phone or camera and upload the video result in social media (facebook). Parents, other students and viewers will give praises, comments and also opinions about this video.

\section{Acting from script}

Playing scripts and acting out the dialogues are two kinds of acting scriptsthat should be considered by the teacher in the teaching speaking activity. Acting from script can be categorized as a play (drama). Courtney (1980) defines drama as "the human process whereby imaginative thought becomes action, drama is based on internal empathy and identification, and leads to external impersonation". In other words, it represents the world of "let's pretend", the act of using imagination to become someone or something other than yourself. Other professionals such as Slade (1958) believes drama is the art of doing in life, whereby one may assume various roles until he finally discovers who and what he really is.

InVLC this activity is practiced by upper classes (e.g level IV, V, VI, and SCC class), because this activity requires long expression, mastering many vocabularies, and role appreciation, Short plays (drama) like cinderella, snow white, simardan are performed by the students in front of the class. In these levels, students can act out their role based on the teachers guiding. There are some activities prepared by the teacher in applying drama (play) as the speaking skill performance. Firstly, the teacher determines the context in which themes and topics suit the learners'linguistic abilities as well as sociocultural background. Teachers can adopt the script from the source books. After that teacher identifies and utilizes a variety of roles for students. Teacher will give the chance to the students choosing what character is suitable for them, but students have to analyze about the characters. The next step is in depth reading of the script, the students try to appreciate the character in the script. They can discuss and ask the teacher if they have difficulty in pronouncing something or expression in English. They also can improvise the expression from the script. In this case, the creativity is needed to 
perform the play better and more interesting. Finally, the students perform the play (drama) in front of the class. Perhaps the performing is not enough in a day, so they can continue the play in the next meeting. The teacher will not forget to record this play, and upload in the social media(face book). Too err is human while to forgive divine. It is a common that the students make the mistakes in expressing the script or act the role, but the teacher keeps the play going on. At the end of the class, teacher will comment and support the result of the play to be better in the next project.

\section{Brainstorming (Prepared short talk)}

One of the popular, interestingspeaking activities in VLCis brainstorming or prepared short talk, where students make apresentation on a topic given by the teacher.In this activity, firstly, teacher will explain the topic/theme to the students, then give the time to them building sentences before practicing in front of the class. Students can ask or discuss with the teachers about difficult expression or pronunciation. They also can browse from the mobile about the topic. For students to benefit from doing oralpresentations, a teacher needs to invest some time in the procedures and processesstudents are involved in. When a student makes a presentation, it is important thatthe teacher gives other students tasks to carry out as they listen. Maybe studentswill be the kind of feedback tasks teachers have just described. Whether there is afeedback or not from the teacher, the students or a combination of both, it isimportant that students who have made an oral presentation get a chance toanalyze what they have done. Teacher also record and upload this activity via mobile phone or camera. This activity is also conducted by high classes in VLC, namely Level and SCC grade.

\section{Interview / Questions and Answers}

Interview or question and answer teaching strategy is an old strategy also known as "Socratic Method of Teaching". It was developed by the famous philosopher Socrates. According to Parke, "the question is the key to all educative activity above the habit-skill level. The strategy is focused on in achieving the cognitive objectives and bringing knowledge to the conscious level. The students should be asked such questions which compel them to think the matter over. If the students cannot answer the question fully, his partial answer should be accepted and another student may be asked to improve upon it.

In VLC interview or QA activity is provided since the lowest class (kindergarten) till the highest class (SCC). In lower class (kindergarten, standard, primary) students will answer the questions in short or simple sentence, but in the higher levels (level, and SCC), they will answer and give explanation in complex sentences. They also can designquestionnaires on any topic that is appropriate and ask the teacher as feedback. Technology is also applied in this activity by recording using mobile phone or camera and uploading in face book. There is also another good strategy and suitable to be followed by other institutionsin Tanjungbalai related to the interview session, where there are some teachers will interview the students out side the class (interview area), and it is conducted everyday in turns. By this extra activity students will have more time face to face speaking in English with professional teachers.

\section{Retelling from pictures}

Retelling from pictures is one of the enjoyable activities to provide students with opportunities actively in speaking English. The researcher will give the students opportunities by retelling story guided by pictures. In this activity, students must retell the passage, text or story by aiding describing pictures in front ofclass. In VLC institution this activity is held in middle and upper classes (primary, level and SCC class) because in these stage students are able to communicate in English by using pictures. Every student gets one picture and must describe it. Thepurposes of this activity are to train students' imagination and retellstory in speaking English. Usually, students feel reluctant tospeak anything because they have very few ideas. But by guiding some pictures, students can express his ideas and opinions to speak in English. Further more students will be easier to say what they see. Thisactivity is very attractive and make students get enjoyable in theclass.

Klasek (1972) states that using pictures have several advantages. First, pictures are the medium of communication, and it is inexpensive and pictures help to manage in events, and can adapt using pictures of many subjects. Pictures are one of the visual aids that can be used in teaching speaking. It makes something more interesting for the students. It also can be used in creating situation for speaking classes more clearly. 


\section{Drilling / Memorizing}

Drilling or memorizingis a rote technique based on repetition. At its simplest, drilling means listening to a model, provided by the teacher, or a tape or another student, and repeating what is heard. This is a repetition drill, a technique that is still used by many teachers when introducing new language items to their students. The teacher says (models) the word or phrase and the students repeat it. Based on the explanation above this activity is suitable for beginner classes or kids learners. In VLC, kids learners practice this activity in speaking skill, because they are new in mastering the vocabularies, lack of words building and cannot arrangewords into a complete sentence. Although this activity belongs to old technique it is very useful for beginner learners. Parents and viewers will be proud and appreciate the children via the uploaded videos, because by praising the children, they will be more interested in speaking English.

\section{CONCLUSSION}

Speaking is one of the important skills that should be mastered by students in order to communicate in English fluently and clearly. Speaking involves interaction with one or more participants. Students always regard it as the most difficult skills to be learned among the four skills (listening, speaking, reading and writing). In VLC institution students practice some speaking activities in teaching learning process, namely drilling/memorizing, play (drama), role play, acting from script, retelling from pictures, brainstorming (prepared short talk) and etc. In doing these activities students still find difficulties for instance limited vocabularies, mispronounce, lack of self confidence, mother tongue dominance, fearing to make mistakes, nervous, feeling shy and etc. Fortunately, teachers always keep supporting, motivating and appreciating students speaking activities in the teaching learning process. Teachers also apply the technology by using mobile phone or camera and upload the students activities videos. In the other hands, parents, viewers and other students can involve and interact in this video by giving comments, opinion and supporting statement making the students happier and more interested to practice in speaking skill. Hopefully, one day the videos result also can be uploaded in you tube or website to appreciate students performance, because more viewers will watch this video, and the best videos will be used as the media for otherinstitutions or schools in teaching process.

\section{REFERENCES}

Brown, H. D. 2001. Characteristic of Successful Speaking Activities. New York: CambridgeUniversityPress.

Chaney, A.L., and T.L. Burk. 1998. Teaching Oral Communication in Grades K-8. Boston: Allyn\&Bacon.

Courtney, T.H. 1990. Mechanical Behaviour of Materials. McGraw-Hill Incorporated. United States ofAmerica. USA.

Harmer, Jeremy. 2007.The Practice of English Language Teaching. Pearson Education Limited. Essex, England.

Klasek, C. B. 1972. International Media in Modern School. London: Macmillan Press.

Ladousse, Gilan Porter. 1987. Role play. Oxford: Oxford University Press.

Nunan, David. 2003. Practical English Language Teaching. NY:McGraw-Hill.

Parrott, M. 2002. Tasks for Language Teachers. UK: Cambridge University Press.

Richard, J.C and Renandya, W.A. 2002. Methodology in Language Teaching: An Anthology of Current Practices. New York: Cambridge Uuniversity Press

Richards, J. C., Platt, J., \& Weber, H. 1985. Longman dictionary of applied linguistics. London: Longman.

Slade, Peter. 1958. An Introduction to Child Drama. London: Unibooks, Hodder and Stoughton.

Tillitt Bruce \&Bruder Mary Newton. 1985. Speaking Naturally, CommunicationSkills in American English.Cambridge: Cambridge University Press. 